\title{
An Error Analysis of Using Plural Nouns in English Sentences" A Case Study of the Second Year Students of MA AI-Manar Tengaran in the Academic Year 2003/2004
}

\author{
Mustaidah \\ English Department of Educational Faculty \\ STAIN Salatiga \\ mustaidah@yahoo.com
}

\begin{abstract}
By doing this research, the writer hopes that the results will be helpful to the English leamer in order to be more careful in using plural nouns in English sentences. The subject of research is the second year students of MA Al- Manar Tengaran in the academic year 2003/2004.The writer uses random sampling by lottery method to get the sample of research. The writer analyses the data by making the observation of all collected data, Categorizing the data by giving codes for cash data, categorizing the data by giving codes for cash data, and interpreting data info substantive theory. The result of the study shows that there are dominant errors which are made by students of second years of MA Al-Manar to use plural nouns in English.
\end{abstract}

Keywords: Plural, Random Sampling, Categorizing, Dominant, Error

\begin{abstract}
Abstrak
Melalui penelitian ini, peneliti berharap hasil dari studi tersebut dapat bermanfaat bagi pembelajar bahasa Inggris agar lebih berhati-hati dalam menggunakan kata benda plural dalam kalimatkalimat bahasa Inggris. Subjek dalam penelitian ini adalah siswa tahun ke dua, MA Al Manar Tengaran tahun akademik 2003/2004. Penulis menggunakan metode random sampling untuk menentukan jumlah sampel. Dalam menganalisis data, peneliti melakukan pengamatan pada data yang dikumpulkan, mengkategorikan data melalui pemberian kode, dan menginterpretasikan data dengan menggunakan teori substantive. Hasil penelitian menunjukkan
\end{abstract}


adanya kesalahan yang dominan yang dilakukan oleh siswa-siswa tahun ke dua MA Al Manar dalam penggunaan kata benda plural dalam bahasa Inggris.

Kata Kunci: Plural, Sampel Random,Pengkategorian, Dominan, Kesalahan

\section{Introduction}

Language is the system of arbitrary vocal symbols by means of which a social group cooperates (Bloch and George, 1942: 5). Every normal human being is a member of a social group, sometimes of more than one, and every human being depends, in all his social activities, on the use of language. Without language, human society is unthinkable; language is the link between otherwise unconnected nervous systems, and thus the means by which the stimulus acting on one man may produce an effective response in another, or in all the members of the group. By using language, human beings can express their ideas and whishes in written or oral form to other people. Nowadays, English is one of thousand languages in the worlh that it is considered as an important language and Engliah must be leamed since the students are studying inElementary School.

Indonesia as a developing country was appointing English is taught as compulsory subject from the first grade of Junior High School up to third grade of Junior High school, and even in semesters of Tertiary Educational institution. So, the student feel difficult to leam English when they study in the Junior High School, because they do not know it before.

In the curriculum of English teaching, it includes skills of practical language, like listening, speaking, and writing. For expanding the student's skill, the curriculum of English teaching also 
include the language components, like vocabulary, structure, and pronunciation (in speech) or spelling (in writing).

Beside for students, a teacher must have teaching ability for making them understand and effort to apply both language skills and language components in class. So, this makes condition alive, or this is not snared in monotone situation in teaching and learning process.

English as a second language for foreign leamer, as corder observes the learners' errors are indicative both of the state of the leamers' knowledge and of the ways in which a second language is leamed. Sentences contained errors would be characterized by systematic deviancy. While the learners, comect sentences do not necessarily give evidence of the nules the leamer is using or of the hypothesis he is testing, his errors suggest the strategies he employs to work out the nules of the new language an the rule he has developedat given stages of his languagedevelopment (Richards, $1974: 1)$.

Errors can be described as errors of addition, omission, substitution, and ordering following standard mathematical categories. Inflectional emors is overgeneralization of constructed rule clearly revealded when children treat irregular verbs and nouns as if they were regular. We have probably all heard children say bringed, goed, doed, or foots, mouses, sheeps, childs. These mistakes tell us more about how children leam language than the correct forms they use (Fromkin and Blair, 1965).

As a majority of noun accumence for number in the surface structure of English are regularly governed by this 'count-uncount' generalization. Count nouns refer to things that can be counted, such as tree, book, bird and therefore have a plural forms. Uncountable nouns refer to 
substances and qualities which we do not perceive in terms of countable units and which consequently have no plural form, such as rice, water, sugar, etc.

Most countable nouns can change their form from singular to plural by adding -(e) s (treetrees, city-cities, book-books) and so on. Although this-s plural is the most common form, there are other so-called irregular plurals (Nichols, 1965). Sometimes, the students have many difficulties of using plural nouns in English sentences because the inflectional plural forms.

Based on description above, the writer would like to conduct a research under the title " $\mathrm{AN}$ ERROR ANALYSIS OF USING PLURAL NOUNS IN ENGLISH SENTENCES” A case study of the second year students of MA Al-Manar Tengaran in the Academic year 2003/2004.

\section{Research Methodology}

The writer has tried to narrange the research methodology systematically in order to capable of analyzing the collected data easily. The research methodology will be organized as follows:

1. Population

Suharsimi Arikunto, in the book Prosedur penelitian, suatu pendekatan praktek, states the population is all members of the research subject (Arikunto, 2002: 108). Population is all individuals from whom the data are collected. In this research, population is the all of students of MA Al-Manar Tengaran in academic year 2003/2004.

2. Sample

A sample is part of populations, which is researched by researcher. In this research, the writer takes the second year students of MA Al-Manar Tengaran as the sample. 
3. Sampling

Sampling is the way of taking sample. For getting the sample of research, the writer uses random sampling by lottery method. In this case, the writer takes all of the second year students.

4. The procedure of collecting data

a. Library research

Lybrary research is use to get the appropriate and relevant books with this study.

b. Test

The instrument is the research is used to know the students' error in using plural nouns and application in the Englishsentences.

c. Format if data analysis

1) To find out the propotionof frequency error in each types as well as the dominant errors by using describtive analysis as follows:

$$
\mathrm{X}=\frac{\sum \mathrm{E}}{\sum T} x 100 \%
$$

Where,

$\mathrm{X}=$ the precentage of error

$\mathrm{E}=$ the various kinds of error

$\mathrm{T}=$ test item

$\sum=$ the sum of 
2). The proportion of frequency of emor was calculated by using the pre-selected category approach formula as follow :

Formula 1

$$
\begin{aligned}
& p i=\frac{\mathrm{fi}}{\mathrm{n}} \times 100 \% \\
& P i \text { : the proportion of frequency of occourred } \\
& f i: \text { absolute frequency of whole type of error } \\
& N: \text { the total number of possible error observe }
\end{aligned}
$$

\section{Discussion}

\section{The Method of Data Analysis}

According to Suharsimi Arikunto, there are four steps in analyzing and interpreting the data, namely:

1. Making the observation of all collected data

2. Arranging all collected data by unifying data

3. Categorizing the data by giving codes for cash data

4. Interpreting datainfo substantive theory.

Based on those steps, the writer analyzed the data using the following steps:

1. Identify the students' dominant errors based on the result of the test as the primary data.

2. Count the students' dominant error in percentage 
$\mathrm{X}=\frac{\sum \mathrm{E}}{\sum T} x 100 \%$

Where,

$\mathrm{X}=$ the precentage of error

$\mathrm{E}=$ the various kinds of error

$\mathrm{T}=$ testitem

$\sum=$ the sum of

3. To find out the students' dominant errors as a whole in precentage

$P I=\frac{\mathrm{FI}}{\mathrm{N}} \times 100 \%$

Where,

$\mathrm{PI}=$ the proportion of frequency of occurrence of errors as a whole

$\mathrm{FI}=$ absolute frequency of error types all the levels

$\mathrm{N}=$ the total number of possible errors of all the levels

4. Interpreting all data collected to find out the sources or causes of the stude nts' dominant errors in using plural nouns forms. 
The writer analyzed the data beginning the first step, namely:

a. Identification the students' dominant errors based on the result of the test.

There are 40 test item for the 52 students.

Based on the classification of possible emor, there are types of error that made by the students.

1). The types of error about form changing by adding $-\mathrm{s}$

\begin{tabular}{|l|l|l|l|}
\hline No & Item Test & Wrong Answer & Error Number \\
\hline 13 & Belief & Believes & 32 \\
\hline 15 & Piano & Pianos & 20 \\
\hline
\end{tabular}

2). The type of error about form changing by adding-es

\begin{tabular}{|l|l|l|l|}
\hline No & Item Test & Wrong Answer & Error Number \\
\hline 1 & Dish & Dishs & 14 \\
\hline 2 & Lady & Ladys & 38 \\
\hline 3 & Dress & Dressing & 11 \\
\hline 4 & Tomato & Tomatos & 25 \\
\hline 7 & Wish & Wishs & 22 \\
\hline 8 & Leaf & Leafs & 34 \\
\hline 10 & Copy & Copyes, copys & 34 \\
\hline 11 & Knife & Knifes & 32 \\
\hline 14 & Calf & Calfs & 34 \\
\hline
\end{tabular}


3). The type of error about form changing in the vocal

\begin{tabular}{|c|c|c|c|}
\hline No & Item Test & Wrong Answer & ErrorNumber \\
\hline 6 & Toots & Tooths & 25 \\
\hline 9 & Foot & Footes & 38 \\
\hline 12 & Goose & Gooses & 32 \\
\hline
\end{tabular}

4). The type of error inregular form

\begin{tabular}{|c|c|c|c|}
\hline No & Item Test & Wrong Answer & Error Number \\
\hline 5 & Ox & Oxes & 34 \\
\hline
\end{tabular}

5). The type of error differentiate between plural and singular word

\begin{tabular}{|c|c|c|c|}
\hline No & Item Test & Wrong Answer & Error Number \\
\hline 16 & Information & Plural & 12 \\
\hline 17 & Job & Plural & 14 \\
\hline 18 & Problem & Plural & 10 \\
\hline 19 & Them & Singular & 22 \\
\hline 20 & Patients & Singular & 12 \\
\hline 21 & Athletes & Singular & 3 \\
\hline 22 & Costume & Plural & - \\
\hline 23 & Gases & Singular & - \\
\hline 24 & Economics & Plural & 32 \\
\hline 25 & Scissors & Singular & 11 \\
\hline
\end{tabular}


6).

\begin{tabular}{|c|c|c|c|}
\hline No & Item Test & Wrong Answer & $\begin{array}{c}\text { Error } \\
\text { Number }\end{array}$ \\
\hline 26 & $\begin{array}{l}\text { A deer is a wild } \\
\text { animal }\end{array}$ & $\begin{array}{l}\text { Deer is a wild } \\
\text { animal }\end{array}$ & 12 \\
\hline 27 & $\begin{array}{l}\text { The mouse ran into a } \\
\text { hole }\end{array}$ & $\begin{array}{l}\text { The mouse ran intoa } \\
\text { hole }\end{array}$ & 25 \\
\hline 28 & $\begin{array}{l}\text { A crunch is a placeof } \\
\text { worship }\end{array}$ & $\begin{array}{l}\text { Chrunches is a } \\
\text { placeof worship }\end{array}$ & 29 \\
\hline 29 & $\begin{array}{l}\text { A box is usually } \\
\text { square } \\
\text { rectangular in form }\end{array}$ & $\begin{array}{l}\text { Boxs is usually } \\
\text { square } \\
\text { rectangular in form }\end{array}$ & 28 \\
\hline 30 & $\begin{array}{l}\text { A child needs much } \\
\text { sympathy and } \\
\text { understanding }\end{array}$ & $\begin{array}{l}\text { Children needs } \\
\text { much sympathy and } \\
\text { understanding }\end{array}$ & 23 \\
\hline 31 & $\begin{array}{l}\text { The bus was very } \\
\text { crowded }\end{array}$ & $\begin{array}{l}\text { Buses was very } \\
\text { crowded }\end{array}$ & 24 \\
\hline 32 & $\begin{array}{l}\text { An easily gained } \\
\text { victory is seldom } \\
\text { appreciated }\end{array}$ & $\begin{array}{lr}\text { An easily } & \text { gained } \\
\text { victoryes } & \text { seldom } \\
\text { appreciated } & \\
\end{array}$ & 22 \\
\hline 33 & $\begin{array}{l}\text { A potato is a } \\
\text { vegetable }\end{array}$ & 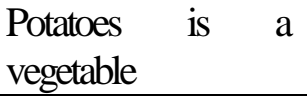 & 14 \\
\hline 34 & $\begin{array}{l}\text { An apple grows on a } \\
\text { tree }\end{array}$ & $\begin{array}{l}\text { Apples grows on a } \\
\text { tree }\end{array}$ & 22 \\
\hline 35 & A fish can swim & A fishes can swim & 12 \\
\hline 36 & $\begin{array}{l}\text { A chair is made of } \\
\text { wood }\end{array}$ & $\begin{array}{l}\text { Chairs made of } \\
\text { wood }\end{array}$ & 14 \\
\hline 37 & $\begin{array}{l}\text { An exercise is not } \\
\text { always easy for } \\
\text { beginers }\end{array}$ & $\begin{array}{l}\text { An excersise are not } \\
\text { always easy for } \\
\text { beginers }\end{array}$ & 12 \\
\hline 38 & $\begin{array}{l}\text { A handkerchief is } \\
\text { made of piece of } \\
\text { cloth }\end{array}$ & $\begin{array}{l}\text { A handkerchief are } \\
\text { made of piece of } \\
\text { cloth }\end{array}$ & 20 \\
\hline 39 & $\begin{array}{l}\text { The fly spreads } \\
\text { disease }\end{array}$ & $\begin{array}{l}\text { The flys spreads } \\
\text { disease }\end{array}$ & 22 \\
\hline 40 & $\begin{array}{l}\text { A watch is simply } \\
\text { small clocks }\end{array}$ & $\begin{array}{l}\text { A watches are } \\
\text { simply simply small } \\
\text { clocks }\end{array}$ & 18 \\
\hline
\end{tabular}


b. In processing the data obtained from result of the respondents test, she used the following formula:

$$
\mathrm{X}=\frac{\sum \mathrm{E}}{\sum T} x 100 \%
$$

Where,

$$
\mathrm{X}=\text { the precentage of error }
$$

$$
\mathrm{E}=\text { the various kinds of error }
$$

$$
\mathrm{T}=\text { testitem }
$$

$$
\sum=\text { the sum of }
$$

\section{a. Table Iprecentage of Error}

\begin{tabular}{|c|c|c|c|}
\hline Subject & Sum of Error & $\begin{array}{c}\text { Sum of test } \\
\text { item }\end{array}$ & $\begin{array}{c}\text { Precentage of } \\
\text { errors }\end{array}$ \\
\hline$(1)$ & $(2)$ & $(3)$ & $(4)$ \\
\hline 1 & 12 & 40 & $30 \%$ \\
\hline 2 & 19 & 40 & $47.5 \%$ \\
\hline 3 & 10 & 40 & $25 \%$ \\
\hline 4 & 24 & 40 & $60 \%$ \\
\hline 5 & 15 & 40 & $37.5 \%$ \\
\hline 6 & 6 & 40 & $15 \%$ \\
\hline 7 & 21 & 40 & $52.5 \%$ \\
\hline 8 & 10 & 40 & $25 \%$ \\
\hline 9 & 13 & 40 & $32.5 \%$ \\
\hline 10 & 18 & 40 & $45 \%$ \\
\hline 11 & 22 & 40 & $55 \%$ \\
\hline
\end{tabular}




\begin{tabular}{|c|c|c|c|}
\hline 12 & 16 & 40 & $40 \%$ \\
\hline 13 & 12 & 40 & $30 \%$ \\
\hline 14 & 16 & 40 & $40 \%$ \\
\hline 15 & 20 & 40 & $50 \%$ \\
\hline 16 & 20 & 40 & $50 \%$ \\
\hline 17 & 6 & 40 & $15 \%$ \\
\hline 18 & 25 & 40 & $62.5 \%$ \\
\hline 19 & 19 & 40 & $47.5 \%$ \\
\hline 20 & 10 & 40 & $25 \%$ \\
\hline 21 & 12 & 40 & $30 \%$ \\
\hline 22 & 19 & 40 & $47.5 \%$ \\
\hline 23 & 10 & 40 & $25 \%$ \\
\hline 24 & 24 & 40 & $60 \%$ \\
\hline 25 & 15 & 40 & $37.5 \%$ \\
\hline 26 & 6 & 40 & $15 \%$ \\
\hline 27 & 21 & 40 & $52.5 \%$ \\
\hline 28 & 10 & 40 & $25 \%$ \\
\hline 29 & 13 & 40 & $32.5 \%$ \\
\hline 30 & 18 & 40 & $45 \%$ \\
\hline 31 & 22 & 40 & $55 \%$ \\
\hline 32 & 16 & 40 & $40 \%$ \\
\hline 33 & 12 & 40 & $30 \%$ \\
\hline 34 & 16 & 40 & $40 \%$ \\
\hline 35 & 20 & 40 & $50 \%$ \\
\hline 36 & 20 & 40 & $50 \%$ \\
\hline 37 & 6 & 40 & $15 \%$ \\
\hline 38 & 25 & 40 & $62.5 \%$ \\
\hline 39 & 19 & 40 & $47.5 \%$ \\
\hline 40 & 10 & 40 & $25 \%$ \\
\hline 41 & 12 & 40 & $30 \%$ \\
\hline 42 & 19 & 40 & $47.5 \%$ \\
\hline 43 & 10 & 40 & $25 \%$ \\
\hline 44 & 24 & 40 & $60 \%$ \\
\hline 45 & 15 & 40 & $37.5 \%$ \\
\hline 46 & 6 & 40 & $15 \%$ \\
\hline
\end{tabular}




\begin{tabular}{|c|c|c|c|}
\hline 47 & 21 & 40 & $52.5 \%$ \\
\hline 48 & 10 & 40 & $25 \%$ \\
\hline 49 & 13 & 40 & $32 . \% 5$ \\
\hline 50 & 18 & 40 & $45 \%$ \\
\hline 51 & 22 & 40 & $55 \%$ \\
\hline 52 & 16 & 40 & $40 \%$ \\
\hline & 824 & 2080 & \\
\hline
\end{tabular}

The next steps was to carry out an error analysis in order to find out the dominant errors that ofen occurred. In this analysis, she used the pre-selected category approach favored by Ethorton as adopted by Norish ( norish, 1983 ). in which the stastical computation is based on Gulos formula:

$p i=\frac{\mathrm{fi}}{\mathrm{n}} \times 100 \%$

Where,

$p i=$ the proportion of frequency of occurrence of error

$f i=$ absolute of partial type of error

$n=$ the total number of possible errors of the level

after the writer had the computation on the proportion of occurrence partially, she then computed the proportion of frequency of occurrence of error as whole, using the following formula:

$P I=\frac{\mathrm{FI}}{\mathrm{N}} \times 100 \%$ 


$$
\begin{aligned}
p i & =\frac{824}{2080} \times 100 \% \\
& =39.62 \%
\end{aligned}
$$

a. Table II The Proportion of Error

\begin{tabular}{|c|c|c|c|c|c|}
\hline \multirow{2}{*}{$\begin{array}{c}\text { Number of } \\
\text { Subject }\end{array}$} & \multirow{2}{*}{$\sum$ items } & $\sum \mathrm{n}$ & \multicolumn{2}{|c|}{ Emors } & \multirow{2}{*}{ PI-pi \% } \\
\cline { 4 - 5 } & & & $\mathrm{Fi}$ & $\mathrm{pi}(\%)$ & \\
\hline 1 & 2 & 3 & 4 & 5 & 6 \\
\hline 1 & 2 & 628 & 52 & 6.3 & 33.32 \\
\hline 2 & 9 & 50 & 242 & 29.3 & 10.32 \\
\hline 3 & 3 & 104 & 95 & 11.5 & 28.12 \\
\hline 4 & 1 & 34 & 34 & 4.12 & 35.5 \\
\hline 5 & 10 & 1160 & 116 & 14.07 & 25.55 \\
\hline 6 & 15 & 104 & 285 & 34.7 & 4.92 \\
\hline Total & 40 & 2080 & 824 & 95.87 & 137.73 \\
\hline
\end{tabular}

\section{Interpreting all data to find out the sources of dominant errors}

In this analysis, the writer made a classification and categorization of errors based on the text-reference. The main purpose on doing this analysis was to trance the source of the dominant errors observed, nsmely the resl error made by the students. Then, the writer classified those errors into two categories of emors based on intralingual only.

1. Ignorance of nule restriction

Ignorance of rule restriction took the proportion of 65,42\% (539 emors). 210 emrors due toignorance of rule restriction occurred at the form changing, as follow:

a. The form changing by adding $-\mathrm{s}$

$$
(52 \text { errors }=6.3 \%)
$$


b. The form changing by adding-es

$$
(242 \text { errors }=29.3 \%)
$$

c. The form changing by in vocal

$$
(95 \text { errors }=11.5 \%)
$$

d. The irregular form

$$
(34 \text { errors }=4.12 \%)
$$

e. The difference between plural and singular

$$
(116 \text { errors }=14.07 \%)
$$

2. Incomplete application of the rules

There were 285 error (34.59\%) due to incomplete application of the rules occurred in the use of plural nouns form in English sentence. This mean that they had no good comprehension or interpretation of the target language.

\section{The possible ways out of preventing those errors}

1. Before teaching the material, the teachers can emphasize the difference the plural nouns between Indonesian and English form, so the students understand them and apply the correct pattem in English.

2. The teacher provides a lot of examples of plural form and ask students to compare English and Indonesian form, so that they really find differences between them. 
3. The teachers also give some excercises to students, so they are abel to make correct plural form in English and abel to apply its in the sentenc.

4. The students can be asked to apply their knowledge about the material. When they get the difficulties, the teacher re-explains the material clearly.

\section{Conclusion}

From the analysis result this research, the writer can conclude that the dominant errors which are made by the students to use pluran noun in english. error in form changing by adding $\mathrm{s}$ (33.32\%), error in form changing by adding -es (10.32\%), error in form changing by in vocal (28.12\%), emror in irregular form (35.5\%), error in difference between plural and singular (25.55\%), error in using plural nouns in sentence (4.92\%).

The possible sources or causes of those errors are ignorance of rule restriction (65.42\% $=539 \mathrm{errors})$ mand Incomplete application of the rules $(34.59 \%=285$ errors). The possible ways out of preventing those errors. Before teaching the material, the teachers can emphasize the difference the plural nouns between Indonesian and English form, so the students understand them and apply the correct pattern in English. The teacher provides a lot of examples of plural form and ask students to compare English and Indonesian form, so that they really find differences between them. The teachers also give some excercises to students, so they are abel to make comect plural formin English and abel to apply its in the sentenc. The students can be asked 
to apply their knowledge about the material. When they get the difficulties, the teacher re-explains the material clearly.

\section{References}

Arkunto, Suharsimi, 2002, prosedur penelitian, Suatu Pendekatan Praktek, Jakarta, Rineka Cipta.

Benard Bloch and George L. Trager, 1942, outtine of Linguistic Analysis, Baltimore, Md., Linguistic of America.

Brown, H. Douglas, 1980, Principle of Learning and Teaching, New Jersey, Prentice Hall. Inc

Frank, Marcella, 1972, Modern English, Englewood Cliffs, New Jersey, Prentice Hall. Inc

Fromkin, Victoria and Blair, David, 1990, An Introduction tu Language, Sydney, London Holt Rinehart and Wirshton.

Gay, L.R., 1987, Education Research; Competencies for Analys and Application, New York, Merril Publishing Company.

Gronlund, Norman E., 1976, Measurement and Evaluation in Teaching, , New York, Collier Mac Millan..

Nichols, ANNEIJenholm, 1965, English Syntax, Holt Rinehart and Winston Inc.

Norish, John, 1983, language learners and Their Error, London, Macmillan Press.

Nurhadi, 1995, Tata Bahasa Pendidikan, IKIP Semarang Press.

Richards, Jack C., 1974, Error Analysis, London and New York, Longman.

Taringan, Henry, Guntur, 1990, Pengajaran Analysis Kesalahan Berbahasa, Bandung Angkasa

Thomson, AJ. and Martinet A.V., 1986, Practical English Grammar, Singapore, Singapore OffsetPrinting Co.Ltd. 
Zandvoort, R.W., 1957, A Handbook of English Grammar, London, Longman, Green and Co. 